УДК 372.212 .3

DOI 10.33514/1694-7851-2019-2-150-153

Оспаналиева Даметкуль Оруналаевна

Старший преподаватель кафедры Технология и искусство костюма и текстиля КГУ им. И. Арабаева

ОКУУЧУЛАРДЫ ЭСТЕТИКАЛЫК ТАРБИЯЛООДО УЛУТТУК КИЙИМДЕРДИ ИЗИЛДӨӨДӨНУН РОЛУ

\title{
РОЛЬ ИЗУЧЕНИЯ НАРОДНОГО КОСТЮМА В ЭСТЕТИЧЕСКОМ ВОСПИТАНИИ СТУДЕНТОВ
}

\section{THE ROLE OF STUDYING THE NATIONAL COSTUME IN THE AESTHETIC EDUCATION OF THE STUDENTS}

\begin{abstract}
Аннотация: Макалада "кийим өндүрүҮ технологиясы Үчүн", "жана камтыйт темасында окутуу тармагында окуган студенттердин эстетикальк билим беруҮ улуттук костюм" материалда Art долбоорду ишке ашыруу "деген мааниге ээ" кийим куруу ". КөрсөтҮY эки баскычтан: улуттук костюм талдоо жана элдик лаган салттары менен заманбап кийимдерди ишто. Бул чындыкка келечектеги мода эстетикальк мамиле түзүY боюнча тартипти таасиринин негизги учурларын белгиленген.
\end{abstract}

Аннотация: $B$ статье раскрывается значение народного костюма в эстетическом воспитании студентов, обучающихся по направлениям подготовки по дисциплине «Художественное выполнение проекта в материале», включающий «Технологию изготовления швейных изделий»» и «Конструирование швейных изделий». Показань два этапа: анализ народного костюма и конструирование современной одежды с применением традиций народного костюма. Отмечены ключевые моменты влияния дисциплины на формирование у будущих модельеров эстетического отношения к действительности.

Annotation: The article reveals the value of folk costume in the aesthetic education of students majoring in technology of the light industry products and construction of the light industry products. The paper shows two stages in studying Folk Costume course: the analysis of folk costume and contemporary clothing construction using folk costume traditions. The article points out the essential elements of this course's influence on the formation of aesthetic attitude to reality in the future designers.

Ачкыч сөздөр: элдик костюм, эстетикальк билим берүY, элдик кийим-кечелери, окуу процесси, түрүндө, конструктивдүҮ элементтери, каада-салттар

Ключевые слова: народный костюм, эстетическое воспитание, элементы народного костюма, процесс обучения, форма, конструктивные элементы, традиции.

Keywords: folk costume, aesthetic education, elements of folk costume, learning process, form, design elements, traditions.

При развитии творческого проекта создаются предпосылки для формирования у студентов активной творческой деятельности, развития эстетического вкуса, образного мышления, пространственного воображения. Важность народного искусства как одного из средств эстетического воспитания является неоспоримой, а народный костюм как его составляющая становится основным фактором формирования эстетического мировоззрения и эстетического отношения к действительности у студентов швейных направлений подготовки.[1] В образах народной одежды заключались духовность, ценности и чувства людей. Е.Н. Гузеватова считает, что организация целенаправленной учебно-исследовательской работы по изучению влияния традиционного народного костюма способствует решению задач эстетического воспитания студентов и развитию 
традиций народной художественной культуры.[2] По мнению Н.А. Муминовой, организация занятий должна строиться таким образом, чтобы у студентов сформировался устойчивый интерес к национальному искусству, способствуя развитию эстетического вкуса.[3] Таким образом, эффективность эстетического воспитания студентов будет зависеть от организации учебного процесса.

Эстетическое воспитание, по нашему мнению, является одним из важнейших факторов, способствующих формированию личности студента, ее нравственноэмоциональной составляющей. Основные пути влияния народного костюма на эстетическое воспитание студентов изучаются в рамках освоения дисциплины «Художественное выполнение проекта в материале», которое проходит в два этапа. На первом студенты проводят полный анализ народного костюма, включающий исторический и графический компоненты. При этом развивается эстетическое мышление, начинает формироваться эстетическое отношение к действительности. На втором этапе студентами разрабатывается современный костюм по мотивам народного, в процессе создания которого активно вырабатывается эстетическое отношение к действительности и повышается интерес студентов к объекту творчества. В творческих работах проявляется эстетический вкус, о его сформированности свидетельствует способность обучающихся оценить народный и современный костюмы с точки зрения красоты и гармонии.

Наличие устойчивого интереса к национальным традициям, культуре, наследию проявляется глубиной анализа, оценивания народной одежды и эмоциональностью образов при проектировании народного и современного костюмов. Знакомство с народной одеждой в процессе изучения и разработка новых моделей способствуют получению студентами положительных эмоций от приобщения к прекрасному.

Народный костюм может оказывать эстетическое воздействие на человека через его природные, конструктивные, художественные и социальные особенности: форму, рациональную конструкцию, особенности материала, композиционное построение, декоративную отделку, цветовую гамму, идейно-образное содержание и национальнокультурное значение. При выполнении анализа костюма все вышеназванные элементы подвергаются тщательному изучению, что способствует выработке эстетического вкуса.

Для народного костюма характерными являются покрой, модельные линии, конструкция, которая зависела от ширины материала, многослойность элементов одежды, насыщенный контрастный колорит и ритмическое расположение декоративных элементов. Используемые материалы были полностью натуральными. Применение при проектировании современной одежды подобных материалов характеризует не только рациональность использования, но и возвращение к истокам традиций, единение с природой, изменение мировоззрения.

На архитектонику и декоративное оформление народной одежды оказывали влияние географическое месторасположение, климатические условия, хозяйственный быт, культурные традиции. При изучении структурных элементов костюма студенты приобщаются к народным ценностям, учась давать оценку гармоничным сочетаниям.

Особое эстетическое воздействие на человека оказывает цвет. Цветовая гамма народной одежды традиционно включает контрастные цвета: белый, красный, черный и синий. Иногда добавляются желтый и зеленый. При анализе декоративных элементов происходит активизация интереса к народной культуре, так как декор всегда носил сакральное значение, был ярким и богатым. При его изучении происходит обогащение художественно-образного восприятия, воображения.

Эстетическое отношение к действительности мы определяем через эстетическую деятельность и наличие художественного воображения. Проектирование уникальных творческих объектов мы используем как средство, повышающее интерес к народному творчеству, побуждая обучающихся сохранить наследие, поделиться с другими и тем самым отразить собственную неразрывную связь с окружающим миром. А для этого необходимо разработать собственный художественный образ (современный костюм), 
основанный на мотивах народной одежды. Данная деятельность пробуждает творческое воображение, развивает творческое мышление и эстетическое восприятие, способствует активному использованию полученных ранее знаний, умений и навыков для воплощения проекта в материале.

Итогом изучения курса становится трансформация народного костюма в современный. Включение народных мотивов и элементов в современный костюм - залог незыблемости традиций. Это показатель того, что народные культурные ценности не забыты. Проектировщик несет в общество народное искусство, тем самым транслируя историкокультурные, духовные ценности для всех.

Анализ творческих работ студентов в конце изучения дисциплины показывает, что:

- у обучающихся развивается эстетический вкус (присутствует гармония в эскизах, работы выполненяются качественно, грамотно, дается оценка народному и современному костюму);

студенты проявляют к работе интерес (анализ выполняется качественно, содержит детализацию и систематизацию материала, использовальзуются дополнительные источники информации, изученные студентами самостоятельно);

- у студентов формируется эстетическое отношение к действительности (при разработке современной одежды используются различные элементы народного костюма, хорошо развивается творческое воображение).

Таким образом, можно сказать, что народный костюм играет важную роль в эстетическом воспитании студентов в подготовке направления «Искусство костюма, текстиля»

\section{Список использованной литературы:}

1. Пармон Ф.М. Композиция костюма. Одежда, обувь, аксессуары: учебник для вузов. 3-е изд., перераб. и доп. М., 2002.

2. Гузеватова Е.Н. Изучение традиционного народного костюма в процессе подготовки бакалавров культуры и искусства // Science Time. 2015. № 5 (17). С. 119-124.

3. Муминова Н.А. Эстетическое воспитание студентов посредством народного искусства // Образование и воспитание. 2016. № 4. С. 6-7.

Рецензент: и.о. проф. Сулайманова Ж.Н. 